\title{
The parisian and political chronicles of Zola (I865- 1872): literary and media matrix
}

\author{
Keywords: journalist, chronicles, community, literary matrix, \\ newspapers
}

\section{Opinion}

Working on Émile Zola"writer-journalist" is a modest and ambitious step, since, leaving aside the critics of art and the literary or dramatic talks, we chose to focus on the Parisian and political chronicles rolled into a considerable body of articles under the title I Chronicles and Controversies in volume 13 of the collected works of Zola Circle of the Precious Book or in volumes 3 and 4 of the New World editions. We wanted to embrace two crucial epochs of our history, the end of the Second Empire and the beginnings of the Third Republic, in a period of 7 years of political decay, institutional blurring and warlike or insurrectional upheavals. How can we cross and characterize genres or fields as rich and interdependent as history, the press or the novel? In this respect the melting pot of the chronicle seemed to us to combine with the unusual immediacy of actuality, the dramatic periodicity of historical events, a literary play and elaboration which we did not suspect in this part of the Zolian work still not widely known but increasingly studied by researchers-as evidenced by the record coordinated by Corinne Saminadayar-Perrin in the latest issue of Cahiers naturalists or the collective work Printing and feathers led by Alain Vaillant.

What was our approach? First, we discussed the historical, biographical and journalistic context of the Zolian Chronicles that we here we can synthesize only briefly. From 1865 to 1872, Emile Zola, ambitious young and rebellious Aix up to Paris, through their paces in the small press and prepares its defenses in political publications through contacts at Hachette with writers, critics and journalists collaborating tree illustrated event, but especially to La Tribune, Recall and the Bell, he married and reflected in its articles the opposition movement in the second Empire, which by liberalizing in 1868 , signed its own death warrant; In the same way, with the advent of the Third Republic in 1870, he echoed as a parliamentary chronicler at the Assemblies of Bordeaux, then at Versailles, of men, of the political practices and debates of those years when democracy was struggling, root. In addition, its columns, while being part of the media matrix of the nineteenth century press (periodicity, community, rubricity), offer a wide variety of themes-from mundane appearances to political life, strolling or meditation on nature or commemorations-among other subjects. They are also part of what Marie-Eve Thérenty calls a"literary matrix", deploying an impressive array of forms (dialogues, speeches, letters) and registers (intimacy, satirical irony, pamphlete temptation) here in particular according to our central study.

The third part of the thesis, we will only mention here that by brief allusions, tried to show through essentially four novels-The Quarry, Nana,"novels of morality," The Conquest of Plassans"novel religion,"and his Excellency Eugène Rougon," novel of politics"how the young reporter tested and elaborated in Articles motives, situations, characters that the novelist could reinvest in developing or transposing them: in the press was also a laboratory of the Great Zolian Work, giving it a little of its color. However, there were two pitfalls:
Volume 3 Issue 3 - 2018

\author{
Claude Sabatier \\ University of Paris-Ouest Nanterre La Défense, France
}

Correspondence: V: Claude Sabatier, University of ParisOuest Nanterre La Défense, France, Email claudesabatier63@gmail.comt

Received: September 28, 2017 | Published: May 18, 2018

on the one hand, in the absence of Zola's theoretical texts himself or declarations of intent in his Correspondence or manuscripts, it was difficult to define principles of romantic engendering of the elements present in the Chronicles; because of the lack of proven traces of the rewriting of articles in novels, for lack of"pre-texts", of preparatory files, it was necessary to try to characterize" a journalistic factory of the novel", to parody Colette Becker, to espouse the fictionalization of chronicles sometimes potentially romantic, such that the 1872 Paris Letters published in the New Tales Ninon of 1874. on the other hand, we had not read the novel text in a teleological approach that way in creative writing that setting the work of a program already inscribed in the Chronicles, but showing, at the cost of multiple crossings, possible filiations, disturbing analogies, or at least a thematic and ethical constancy, beyond the years, historical events or evolution of readership.

Before recalling the context of the articles studied, it is important to define the chronicle in the historical sense of the term, in its worldly and then popular sense, in order to understand the meaning that Zola wishes to give it or give it back."The collection of historical facts reported in the order of their succession", the medieval chronicle aims at both to account for time in its linearity, its chronology without necessarily indicating the causes nor to show the sequences and to capture it in its symbolic essence: Froissart, Villehardouin or Joinville not only tell the crusades or the reign of Saint Louis but choose typical, repetitive, admirable moments-constructing a legend or hagiography. Pure succession therefore also postulates an exemplary, symbolic value.

At this historical background will add a double journalistic sense, rained late s, thus formulated in the Larousse of the XIXth century: "newspaper article containing the facts, the news of the day and the noises of the city", on the one hand, the epic gesture becoming, oral tradition, rumor-news true or false, hence the notion, pejorative, of"echoes", Of worldly chronicle or popular", guided by a superficiality, an insignificance denounced by many journalists themselves, periodical, on the other hand, offering a reasoned and oriented magazine of the actuality in a given field., often literary virtuoso, of a rather vain currentity and the substantive article in which it will be less a question of telling one event than of waiting for the deadline to measure a change, understanding the scope of elapsed time: to the antipodes of its primary function-to account for the flight of the days-the chronicle will therefore measure a modulation-the 
variation in repetition-and the predictable or the routine of the cancan give way to the unusual.

It is precisely this vocation to alert, to shake, to worry the minds Zola assigns chronicled in his Letters of curious. These two new texts, written in spring 1865, L'Avenir national, offer a manifesto of chronic, marrying in their approach semantic evolution of the genre-or rather, reviving, beyond journalistic fading, with the original purity of this concept."I know that the word chronic means nothing more than the statement of facts as they present themselves. Let us change the word then to change the thing [...] you want a chronicler and I can only offer you an undisciplined columnist who will be perfectly ignorant of the seasons and the holidays. To the worldly and superficial curiosity of the elegant and bourgeois chronicles, the author thus opposes the intellectual curiosity of the moralist and the historian." I shall try to surprise only the truths. In a word, I am determined to talk at length on a single subject every single Saturday, laughing at a contemporary tale, applauding or whistling the great man or the great event of the day. The Zolian chronicle is thus all the more likely to assume the magnitude of an editorial-a talk or a satire-that, far from offering only an observation, it intends to propose an analysis and an explanation of the causes. "I would dream of a man of taste and talent, staged and abysses in this text, to meet a man who saw in the chronicle a satirical review of our society. He would summarize in strong and rapid features all our vices and all our virtues. He would speak of such a fact only to go back to such a state of mind, he would recount the gossip only to paint the gossips". Intellectual curiosity but also" scientist in the naturalistic sense that this epithet would assume for Zola: "we would-he continues-a columnist in the large sense of the word a moralist who would tell us his time, pulling the string of characters and scrolling century before our eyes. He would write the detached scenes of comedy, contemporary drama; each of his articles would be the study of one of the corners of our society and he could thus, with time and courage, give us the whole work, the history of men and things."It sounds like the founding project of the Rougon-Macquart in the preface to The Fortune of the Rougons or Zola's response during the release of Thérèse Raquin to Taine critic's friendly advising him to work more background and colors his drama by too uncluttered and monochrome.

If the first Zola articles dating back to 1863 , in Le Petit Journal, his real debut in the press, encouraged by its leader status of publicity at Hachette and editor of bibliographic or literary magazines, can indeed be dated Confidences a curious, published as Letters curiously in 1865, in the Mail literary, artistic, industrial and financial Eugene Vattier. The light commentary of the news is for the moment the only way offered to the young journalist in these times of imperial censorship, the liberalization of the press only intervening in 1867, Zola stages Pandore, a curious and frivolous stroller distilling anecdotes and allegories worldly news, artistic or political: the first Confidence evokes the funeral of the Duke of Morny, the publication of the History of Jules César ... by Napoléon III and the parliamentary session of the Senate and the Corps legislative. The character Pandora allows it to mimic the lightness of the small press while satirizing insipidus leveling information as in the articles by Timothée Trimm Le Petit Journal: mask columnist-it"gives appointment to all the baths Aix-en-Provence" and promotes Tales Ninon-it embodies the supposed feminine banter and affects the false naivety of a Persian or a Huron."All white and pink, smiling and frightened, I present myself to you, indecisive, the mysterious box in the hands ... It is false that the box that Jupiter gave me contained only evils: it is false that I opened the box with the suddenness of a little fool who spends in one day all his secrets every week I'll open a little for you. I'll tell you what is unexpected is in escaped, of what wound or bliss I endowed the earth."

The following chronicles, beside the leitmoitv of the chestnut trees (the return of spring, the approach of the holidays) sketch themes that we will find in the articles given to the republican newspapers: the preparations of the Salon, with the procession of a group of artists such as Claude band of friends and Sandoz in early the Work, the medal given to the portrait of the Emperor Cabanel rather than Corot and the reason for the award merit or the Academy, four candidates making a common cabac to solicit for the election of April 6th which will see Camille Doucet and Prevost-Paradol triumph. Tasty, the anecdotes dot the following texts, such as the story of the druggist duped by his daughter and his lover to seek at his request a miraculous grass, that of the duke, violently rejecting his mistress, a humble porter who had the bad taste of waxing his shoes-not to mention the apologue for the"ti-tila-ri-ton" 'monster spider' and"Spider drinker oil" heralding perhaps Archangias characters in the absence of Father Mouret and Faujas in The Conquest of Plassans! The "coup d'epingle" is therefore made sharp for religion at the approach of Holy Week but also for Fashion, "despotic queen who forces all faces and all turns to accommodate even "with" as innovation, Steel everywhere"- disturbing echoes of chronic Timothy Trimm in the Petit Journal April 16, 1865 entitled" eccentricities Longchamp".

With a hymn to the Verrieres woods appears in these Confessions of a Curious another vein, which innervera subsequent articles and will even be a real formal reinvestment "What the wood" published April 12, 1870 in La Cloche chronic-or meditative stroll, the two do not necessarily confusing,"outdoor sketch" and"temptation of artist journalism" according to Henri Mitterand, which can certainly be a kind but can also be explained by contextual considerations: the vacuum of the season, the imperatives of censorship or the traditions of the media periodicity. It should be noted that the motif of nature, a pretext for an animal caricature of Sainte-Beuve and Guizot in frogs and scarabs recycling monster and oil-spider spiders, is subtly linked in both texts to current events political, by the mise en abyme of the newspaper as an object carried away by habit in walk, symbol of textual heterogeneity and effect of reality in its brutal irruption: here the assassination of"this great citizen", Abraham Lincoln no doubt, acquittal at the trial of Tours of Pierre Bonaparte, assassin of the republican reporter Victor Black, whose"forest" the forest ... Preludes pleasant to a writing more conformable to his temperament, these nine texts none the less sharpen Zola's satirical verve, that sharp look of moralist on conformity or bad taste, while sketching the three major forms of the chronicle: chronic Parisian, otherwise worldly and artistic, chronicle-walk or reverie artist, political chronicle.

These three aspects characterize quite well also the 77 articles proposed by the edition of the Circle of the Precious Book and published in The Event illustrated, La Tribune, The Reminder, Hugo's diary and La Cloche, between 23 April 1868 and 17 August 1870-Zola was published between 1866 and 1868 as art criticism and literary or theatrical talks 26 articles on fashion, entertainment, awards or criminal voyeurism appear in The Event illustrated; 31 texts, more creaky in moral denunciation, political and military, more varied as on the literary map, included in the Tribune; The Reminder will only see 6 contributions Zola coded and symbolic, citing the decline of the Second Empire-the luxury insolent face destitution, political 
impunity and clerical disaffection bail to hide the real country and the army engaged in an adventurous conflict; Finally, 14 sarcastic and allegorical texts published in The Bell ringing the kill plan and a moral and political decay in the Quarry and Nana are novels. Political chronicles predominate with about 50 articles, around the people, poverty, the press, imperial power, religion and the army. There are 24 chronicle events-artistic, social or judicial-evoking art, literature and theater, populism and its counterpart, theatrical voyeurism and especially judicial, women, linked for Zola to corruption and artifice, rewards, caricatures of true merit, education of girls and education in general. On the other hand, chronicle-walks, celebrating nature, are sparser: there are only about three of them. It should be noted that these themes or genres are often crossed, as well as the corruption that comes from a satirist discourse on the women, fashion and coquetry, but, more profoundly, summarizes for the pamphleteer journalist the essence of the regime honni. To better situate the context, let us recall the conjunction of three factors: Zola, in these years 18681870 , experiencing financial difficulties-he borrows money from Manet-finds in the press a means of subsisting and exercising his pen when the Republican opposition, around Eugène Pelletan or Théodore Duret, takes advantage of the liberalization of the presswith the abolition of PRIOR permission-to acquire a newspaper like the Tribune, war machine preparing the elections of July 1869. Meanwhile, Zola began writing his Rougon-Macquart with the soap opera the Fortune of the Rougons given to Century-as he had proposed in the event illustrated Madeleine Férat or The Mysteries of Marseille. From this interaction between the press and the novel as well as from political circumstances Zola draws an incisive and virulent style:"it needs this expiring Empire [...] It attacks it by using stylistic violence as a dissection instrument"says Martin Kanes in his Zola workshop, the novelist in the making suggestive in its original plans Rougon-Macquart" masterly build. But still the heat of passion a torrent rumbling but wide and a majestic approach."

This collusion of talent and public life, dating and necessities explains more clearly the entrance Zola Recall, created by Charles Hugo and Henri Rochefort among others, May 4, 1869, in full election campaign and banned before His birth! He enters through an invitation from Paul Meurice, a friend of Manet, which he praised the Cadio drama. The urgency of the struggle against the Empire forgets the aesthetic oppositions between political liberalism and realism, let alone the literary naturalism: Louis Ulbach, director of The Bell did not like Flaubert and we remember his hardness against Thérèse Raquin, in his speech a"putrid literature". Note that The Reminder, seized and banned from publication in June 1869-a paradox of press liberalization replacing oppression by persecution in the words of Hugo-formally presented also as a stirring diary, with its very jagged Articles, its echoes and gossip, its satirical undertones and dialogues, its diatribes against censorship or governmental communiqués: its fragmentation and its disparity offered the young journalist a fine example of a"media matrix", in the sense defined by Marie-Eve Thérenty, with the combat community, the attractive rubric of its presentation and the polemical, so to speak electoralist, periodicity of its publication. However, one article be published in 1869, then we will count 6 for the first months of 1870. Incidentally, two new columns, remained in the papers of Paul Meurice, were found by M. Sanders and commented in No. 52 naturalists Notebooks (1978):"Music of Offenbach" article"striking" and"graspable" according Meurice and"Poor prince", sarcastic text against Pierre Bonaparte.
If the cooperation of Zola Recall stops a few months, the Republican opposition radicalization after the strikes of miners, bloody incidents of Aubin and the assassination of journalist Victor Black quickly bring the journalist in Hugo's circle: special issue Soldiers calling for a detached republican army of imperial power and the proceedings against Henri Rochefort inspire him chronic"the true friends of the army" and the acquittal of Pierre Bonaparte scathing article"the Empire is saved"evoking the cowardly relief of the Emperor's relatives at the funeral of Victor Noir. On 3 February,"What the poor girls dream of", constructed as a diptych, opposes to the misery of a young worker in her galetas the insolent luxury of power, exhibited by the specular process of the inserted newspaper that the poor read" daughter": the description of the toilets at the last ball of the Tuileries, from an article in Le Figaro of 29 January 1870. Double real effect and so romantic promise, as the same passage will be recycled in the description of the dress Renee at the beginning of Quarry ... collaboration Zola Recall to stop after an article on Balzac, according to Paul Alexis, probably displease for the worship of another master Hugo and the"critical realism", devoid of all otherworldliness, loaned to the author of the human Comedy in his own environment and the rising bourgeoisie.

Zola will then enter February 2, 1870 the daily La Cloche-born meeting of its political development and radicalization of Louis Ulbach aka Ferragus, which says"the absolute enemy of a regime that hurts our pride, our conscience and . common sense"with its sassy headings" parliamentarians chimes"," the political comedy"or" box slander,"the newspaper relentlessly criticizes the repression of December 1851 against the resistance to the coup: the soap opera the Bagnes Cayenne, Memories of a political transported to Guyana, L. Pascal exalts the character of the political transported, which will play in the Paris Florent Belly and Arthur Ranc, future Communard, denounced the plebiscite of May 8 as"'a permanent coup (t)". Zola publishes up to 17 August 22 articles. The first fall over the satire of manners and worldly clericalism of political controversy, one thinks of his talk of 2 February"Au convent" which features two young salon dolls, Lucie and Jeanne, who, under the guise of little fools, hide secret heats and tongues. In"Catherine", April 18, he draws from identical theme political conclusions:"The Empire has perverted up to the dolls of our children." The Fast"and then" The Little Chapel"will describe the swoonings of a devout, conquered by the eloquence of a vicar gentleman and ladies of high society who want to have all their private chapel, new boudoir! We know what extension to these texts will Conquest of Plassans.

The following texts-'What the woods say", "La Folle", "His rustic majesty"-are satirical fantasies, while political news is more directly dealt with in" Decorate it" or"Les Gaietés from the room". But on February 17 with "The End of the orgy," Zola finds the strident tones of his indictments of Tribune denouncing the opulent wealth of the profiteers of the "spoils"-the second novel of the Rougon-Macquart is running-and portray the "mute desire" of the people. The chronicle of'Shrug of the Marquise", published on February 21, is in the same register of moral diatribe in less virulent, more ironic and allegorical, in the image of 'What a Girl Wants poor" in The Reminder. The last articles will testify to the boldness of the journalist in the context of the war declared by the Emperor on 17 July. He does not hesitate to take risks, to the point that the director, Louis Ulbach, must remind him to be cautious to avoid Mazas. The Zolian inspiration passes from the moral pamphlet to a speech violently anti-bellicose while the governor censures the communication of military events. In an 
intimate and pathetic text, he dreams, on July 25 , about" Le Petit village", now unknown, lost on a map of the theater of war and of which" tomorrow the river will be red. A New name in history:"it will live forever in the ages like cut-throat a shady place where two nations will have slain." The penultimate article, "Vive la France", celebrates" on the banks of the Rhine the fifty thousand soldiers who said no to the Empire," proclaiming that "the Republic is there on the banks of the Rhine Rhine." alike call for the lifting of a republican army defending France against Prussia and the Empire and denunciation of recovery by La Marseillaise small slashed the official journalism that messed patriotism could that the newspaper and its editor of the legal proceedings that the defeat of Wissembourg and the proclamation of the state of siege will spare them. The bell will stop its publication on August 18, the day after a final article of Zola "Nerves of France", which affirms its confidence in the resistance to the advance of the Prussians. Similarly, the issue of serialized Fortune Rougons will be suspended on 11 August.

The beginnings of the Third Republic will offer Zola matter of articles for Semaphore Marseille but especially many chronic data to The Bell, which will be the parliamentary correspondent in the Assembly of Bordeaux and Versailles; but before acquiring this official status, Zola leaves for Marseilles since September 7-his rebellious pen and his anti-bourgeois speeches do not leave him hoping for an official position with the Republicans in power. He contacts Emile Barlatier, director of the largest and former regional daily Le Semaphore of Marseilles and Alfred Arnaud, owner of the Messenger of Provence who published his Mysteries of Marseille. Taking advantage of the climate anticlerical, anti-Bonapartist or insurrection of the city under the administration of Esquiros former colleague La Tribune, he created with the help of his friend Aix Marius Roux, the newspaper La Marseillaise, which appear as 2 month and a half, from September 27 to December 16. Only 6 Zola items had been returned and published by The Messenger of Provence until recently Adeline Wrona found at the BNF certain numbers of the entire collection. If he has to sell his newspaper Gustave Naquet, Zola reserves the right to write and that is a new leaf, True Republic, supporting moderate candidates in municipal elections, as a springboard in the mind of the novelist to the sub -prefecture of Aix never obtained despite multiple approaches. Otherwise, rushing to Bordeaux where the power was down after the evacuation of Tours, he became the secretary of GlaisBizoin, his former manager at the Tribune, became a member of the Government of National Defense. It will then offer its services to the Bell Louis Ulbach. The 6 items of La Marseillaise, proposed by Patricia Carles and Béatrice Desgranges in Volume 4 of the complete works of Zola to the New World Publishing, striking in their patriotic vehemence and duality, reaffirmed Paris and the province leitmotif of The Republic march: discerned by their titles, "La Marseillaise", "to arms", "the Mourning Srasbourg" after the symbolic fall of the cradle of our national song, "Paris is counting on the province"," Garibaldi "and" Bismarck head "theatrical caricature of Prussian Machiavelli sneaky machinist. The same theme reappears in the texts of True Republic, which call for the "recovery of Orleans" brocardent "the pen of M. Bismarck" who sees himself sign the Paris Peace; in "Men are Missing", he celebrates both the eruption of the torrential people embodied by the National Guard as the Republican army and "energy men" in "their sovereign grandeur and their sovereign truth"-swing between praise and mistrust of the crowd in his work.

From February 1871 to August 1872, Zola, parliamentary reporter, will therefore give La Cloche but also Marseilles Semaphore considerable number of articles grouped by Jacques Kayser under the overall title of The Republic on."'Installed in the early days to the press gallery, he stood on the lookout for new, corridors noise; all the rumors came from side to side. His articles, written at random, gave its Paris readers a colorful and dramatic story, sometimes emotional, sometimes sarcastic, always lived, discussions which played the fate of the country. Gambetta fallen, positions changed hands. But Zola now spoke perfect detachment of one who $\mathrm{n}$ 'has nothing more to prosecute'-explains Henri Mitterand. Zola left office at the beginning of May 1872, before Thiers left. These articles are divided into large chronological units, the continuity of which will be interrupted only by the Commune and the parliamentary holidays. A first series, entitled Letters of Bordeaux, appeared in La Cloche 13 February to 15 March 1871. Zola evokes the first sitting of the National Assembly, the resignation of Garibaldi, the election of Thiers at the head of the executive, the growing disagreement between the province and Paris, the debate on the conditions of peace in Germany-a sharp wound that the Frankfurt Treaty, whose expectations and announcements are staged in a panting and pathetic logbook, finally the announcement of the transfer of the Assembly to Versailles, another heartbreak this time inside for Zola and the true republicans, which seals the divorce between Paris and the province, obsessive leitmotiv chronicles.

Back in Paris March 14, 1871, Zola takes his collaboration with La Cloche. Lives in La Condamine Street Batignolles, he must take every day the train to Versailles, where now sit the Assembly. He did not attend the opening session, on March 20, two days after the proclamation of the Commune, having been momentarily stopped when he was about to leave Paris but will write a report secondhand. Two days later, March 22, is a commissioner of Versailles holding the exit of the station. These two opposite mishaps that have at least the merit to back to back in his mind and Communards Versailles early in the war, do not interrupt this first phase of his work, which ends April 18 with the suspension of La Cloche by the Municipality. A first series of records of the meetings of Versailles covers the period from 20 March to 18 April 1871. Zola described the first sessions of the Assembly in Versailles, the attitude of members to Paris and the Commune, recounts the vain attempts conciliation, analysis interventions or decisions of Thiers, the Local councils Act and the Press Act.

Meanwhile, collaboration Zola at Semaphore of Marseilles, April 25 to June 7, also known under the title Letters of Paris, if it seems out articles of La Cloche offers major interest: it overcomes until June 6 deficiency of articles from Louis Ulbach log, which reappear only on 30 May and we offer very hard passages on the Commune if a different view of chronic La Cloche we were able to challenge the allocation Zola. Let us briefly recall, failing to open a long debate here, Zola, now in Paris at the beginning of the uprising on 14 March must face a threat, real or supposed, arrest, from Saint -Denis May 10 and 13 Bonnières -"voluntary exile" that Rodolphe Walter recalls in an article of naturalists Notebooks. Despite his initial sympathy for elections to the Council of the Commune, at the risk of displeasing the management of his newspaper, the journalist expressed his rejection of the "terror" against the clergy or owners, searches or requisitions and the Committee public salvation, which gives the movement, led by him as "the rebels of the City Hall," a revolutionary turn. Feeling threatened with arrest as a hostage, he fled with a Prussian passport: his collaboration with La Cloche, suspended, would have displeased Raoul Rigault, delegate of the Commune to the General Security, not to mention the siege psychosis and anonymity lifted his correspondence 
at Semaphore. Informed by courier and by the Parisian newspaper or Versailles reaching it, back on May 26 in Paris, he will discuss the bloody week and with deep compassion deplore the massacre of the Parisian people.

Bell reappears on May 30. Zola returns to Versailles that June 6 His parliamentary correspondence resumes 8 . It will be only interrupted by the holidays of the Assembly. These eleven months can be split into several phases. A second round of Versailles Letters covers the period from June 6 to July 2, 1871, when by-elections which marked a return to the left. Zola says is the repeal of the laws of exile striking the Orleans princes, investigation proposal on acts of the Government of National Defense, the history of negotiations with Germany, the powers of the Pardons Committee finally the law on general advice. A third round of letters will from 3 July to 18 September 1871. During these two and a half months, the Assembly, having increased its Republican majority vote of essential laws: the law on bail newspapers, the law on the organization of councils, awarding compensation to the invaded departments, the extension of powers of Thiers, the dissolution of the National Guard. Zola also comments not hide his hostility to the Church, who engaged the debate on France's relations with the Holy See and on the part of religious instruction in education. A fourth delivery, more literary, ranges from 21 September to 26 November 1871, during the parliamentary vacancy: these fourteen satirical articles on Versailles, the monarchist deputies, the Assembly committees. The parliamentary session is the subject of proceedings of 6 December 1871 to 22 January 1872 on the bills on taxes or the appearance of the Orleans princes. The deputies refused to vote the principle of a tax on raw materials demanded by Thiers, the latter resigned, then resumed at the request of the Assembly: it remains "the man needed." In a sixth time, from January 22 to March 30,1872 , the sessions are devoted to new tax and trade agreements, the choice of the seat of the Assembly, which will remain at Versailles, the reorganization of the judiciary, the vote of the Press law and International law. MEPs split between March 30 and April 22. A seventh period, more sparse writing, would run from April 17 to May 3 Zola published two articles, 17 and 22 March: A Tribute to Thiers and a plea for the return of the Assembly in Paris. In September, he even wrote a few columns on the discussion of various bills and on May 3, he bade farewell to the Assembly."I swear-he exclaimed-not set foot in Versailles that when the dissolution will be pronounced."He did not keep his word. Indeed, the eighth and final period, from 23 July to 3 August 1872 sees the new drafting records of meetings, interim replacement journalist who had succeeded him.

The many items of the Republic running could be divided into three major themes: the moral, religious and cultural issues-related in the last chronicles the moral order and in place of the Church; technical, economic or legal-but not always attractive recurring, especially around tax; political debates or politicians who are critical and obviously occupy more space: the war, the Commune, instead of the press or the monarchists quarrels, not to mention the resurgence Bonapartist. The first inspiration holds 17 items, 1 at the beginning of the Republic started on February 25, 1871, 6, scattered in the central periods I to III, marked by the town and its consequences, between March and August 1871 the 10 more coming together between December 1871 and April 1872, with a new stiffening of the moral order which prefigures the fall of Thiers on May 24, 1873. the topics are twofold: culturally, the defense of an instruction secular, including the appointment of teachers by the state or municipalities ; religiously, political issues from the clerical activism and the fate of the pope, threatened by the Italian unit and the ambiguous policy of Napoléon III, both pro nationalities and anxious to spare the Catholic ; the Moral Order atmosphere maintained by the grimacing puppets right tirelessly denounced by Zola, either generally, for their refusal to amnesty of the Communards, their demands for action against the International, their moralism clerical, either the occasion of specific events (festivals schools in Lyon considered by Catholics saturnalia !) or specific debates (the birthright, alcoholism or natural children). A second set, larger, 42 articles, covers the commercial, financial and politico-legal issues that come in treaties, taxes or bills. Articles related fall through the collection and the reporting period, with hotspots from the beginning of the scheme (the issue of the loan, or war indemnities regarding invaded departments), recurring problems with strong hints policy (decentralization and the establishment of the councils, which oppose republicans and monarchists), or during the opening of Parliament in December 1871 the heated debate between Thiers and the Assembly on the commercial treaty with England, the alternative of income tax, rejected by Thiers or tax on raw materials, which has its preference. The Treaty and the two major taxes result in true soap operas, a pretext for a fierce political battle, not to mention other technical matters, taxes or sporadic taxes.

Other articles-about 131 texts-relate to the policy itself. A number relates journalism (the supposed offenses release, the obstacles to its mailing); long chronic, dramatized in soap operas, evoke war, martial law and especially the peace treaty, national trauma with its local sales and financial benefits. Zola, often passionate or critical, sometimes bored or disenchanted, echoes politicians debates that agitate the Assembly: the quarrels of parties on the parliamentary legitimacy of the Orleans princes we do not know if they serve or not the aftermath of the second Empire (the pensions of 1851 judges, joint committees, the return of the Bonapartist Emile Rouher condemnation of the regime compromised with monarchists), the indictment by the monarchists of September 4, the Communards (tips war, amnesty and pardon commission, deportations) and the International against which foments a bill; the unity of the nation or the issue of Paris and province (the communal status of the capital, the National Guard, the contrast between Paris and the provinces-misunderstanding the disaster of the City), the seat the Assembly; institutional debate on a Constituent Assembly and the nature of the regime, original sea serpent. Faced with these procedural delays, this institutional uncertainty, Zola, he condemns the executioner of the Communards, often paid tribute to the political delicacy of Thiers, who, together with the authority of a Eugène Rouher will inspire him the character of Eugene Rougon in Son Excellence Eugène Rougon . A subtly paradoxical maxim reflects this fascination with the political animal:"Caution, home, born from the same battle and his tenacity have unexpected compromises."

Let us now to "literary matrix" in which flow these texts, relying on categories considered under this term by Marie-Eve Thérenty in Literature every day: the fictionalization, akin, if it were need many chronicles stories-symbolic or dreamlike, dialogism, analyzed by Sandrine Carvalhosa in his article in Cahiers and intimacy, loitering or"Zola and chat a learning oblique writing (1865-1870)." meditation. At the heart of this textual typology, it seemed to discern, in the polemic force that drives the chronicles of the Second Empire as parliamentarian's articles, accents or pamphleteer temptation that often dominates a happily or ferociously satirical temperament. Zola fictionalises number of items: faithful in this to a narrative aesthetics of the small press like the so-called serious press, he plays to stage in fables or anecdotes of real or fictional characters, more or less 
dreamlike situations-the literary development of these "activists fiction" (as recalled Corinne Saminadayar Perrin in Article opening the folder of Cahiers "Zola journalist: history, politics, fiction"), offering face a subtle censorship of masks, screens, apologues or allegories embedded and supported by a second narrator; Moreover, aridity or boredom parliamentary debates and political challenges call for both storytelling and dramatization of the mentioned events. The discussion on income tax which opposes Thiers compensate its technical by its many twists and radical pronouncements, the Chief Executive placing his resignation in the balance to better remove once victorious. Similarly, the announcement of the peace treaty seems to absorb the content in the staging of unbearable waiting, her distilled in a burst log and the symbolic dramatization of violated values-honor and country humiliated by annexation or indemnities. Conversely, the inanity of a character like Chaurand Baron and the arrest planned but always postponed, it is unclear on what in February 28, 1872, resulting in a grotesque psychodrama, a false story panting, ending with the death of exhausted mail announcing Marathon as a new deadline.

This narrative tropism wins descriptions, portraits or action, such as the satirical evocation of a monarchist deputy whose seriousness ridiculous triggers "swarms of laughter" animalized here, as if his words or actions were planned in appearance stiffness:"We did not imagine what strength there is often comic in the bottom of the gravity of a man like Mr. Marc Girardin. In the folds of his black coat, in the folds of his white tie, laughs are carpets, small playful laughter that fly through the beautiful days like butterflies bands. Mr. Marc Girardin has unleashed a swarm of his laughter."A surprising modality of journalistic fiction is fantasy that allows both to tell the boredom of some parliamentary sessions and hitting inanity in a marine reverie the last meeting in Bordeaux, the "greenhouse" parliamentary or fusional claims two monarchist camps, surrounded by fairies and wisps:"I imagine-writes columnist-all those good old, fell in love with a vision that crossed the park of Versailles, one evening, at dusk this. A celestial apparition, a white and pink fairy, a shadow of joy and delight, and that's fallen into dementia. They want to own shadow. They throw themselves in pursuit, believe discover behind each rose hips and take that moonlight when they extend the hand."The fantasy is seen doubly weakened: as such, as mental structure monarchists and its contents even an impossible restoration.

Chronic"Mardi gras: the dream of Zola", is entirely a dreamlike narrative, based on allegory and metaphor spun the ball and carnival, where the gentle reminder of journalistic status Zola sounds like a return to reality "I imagined, velvet on my dressing room, be at the Opera, a Saturday night." The session of the Assembly becomes festive Mardi gras and even large text fable where each character, each political group is coded, metaphorically connoted. Masks, party favors and false noses invade the decor. And quadrilles, minuetsup to the amazing stuffed Mr. Rouher fat beef-to deploy with the thousand colors disguises: the monarchists in cherubs, black bears and hedgehogs, the radicals-the capers too discreet-by blacksmiths or ghosts, plus two" Communards well recalcitrant" the allegory developing arsenal of satire and caricature. If the news item often takes the form of portraits evoked narratives staging orchestra he also leads in intention both educational and literary, create skits that reflect the dialogical dimension of the newspaper. As Corinne Saminadayar Perrin recalls in The Journal of Speech, interlocution is consubstantial to the press, which develops" a permanent dialogism with crossed words that constitute its own space: the press is constitutively polyphonic.'In fact, the newspaper not only suggests parliamentary speeches, political debates, worldly conversations but mostly it postulates a dialogue daily with the player and the event, in the immediacy of the article or periodicity of chronic. It is as if he "recreated (is) in the space of the page a form of literary sociability disappeared with the former exhibitions Plan". Recall that Girardin opened one of the first newspapers in the controversy: his columns will welcome about the opponent or, sidebar,"letters to the editor." The name"Hansard"to a respected Orleanist sheet or the title of "chat" Zola gives more of his columns are symptomatic of this aesthetic of closeness and complicity with the reader. One cannot wonder that the press affects the lightness and the oral familiarity because it is not until political discourse that tends to restore the art of conversation, such as those of Thiers seemingly unorganized, punctuated with "spikes" and "humor" but in fact guided by a profound design. Dialogism is an irreducible modality only dialogue can take many forms, those of speech, dialogue itself or letter, polyphonic despite appearances. Playing a lot of enunciation, it suggests multiple or polyphonic voices: those of the author, an opponent, an opponent during a debate or a single interlocutor in dialogue, those of a real or fictional letter writer, a recipient himself or fictitious or énonciataires-control in an open letter. The speech course occupies a prominent place in parliamentary chronicles where the evoked fictionalization bypasses technicality about or avoid a detailed account using a variety of strategies: the narrative of words, the reference in the minutes Official Proceedings -"We have had the speech of M. Thiers against the income tax. I refer you to that document, too long and too complicated for me to venture to analyze," writes columnist-preterition -" I will not discuss this long speech, where the speaker repeated his first arguments"or even the mere mention of the speech, a pretext for a satire or caricature portrait" Mr. Duvergier Hauranne made a long, too long speeches in favor of the income tax it is a cold speaker. Methodically it is still unaccustomed to the rostrum. He looked at over ten times its transitions in its sweet water."

The official discourse often seemingly agreed or tedious Zola is in the fictional discourse chronic Second Empire he will deploy his literary talents. The conversation published in La Tribune August 15, 1869 is symptomatic in this regard: it evokes for him against a potential speech, modernist and generous, the agreed and nostalgic speech on traditional culture, ancient scholarship, given by the Minister of M. Bourbeau public Instruction during the prize open competition at the Sorbonne. The beginning of the text sets the tone:" Ah! What speech! A student of rhetoric who committed often similar would certainly not have been known to hear that warm and bland prose which M. Bourbeau drowned her audience."At this" lukewarm and bland prose,"this" fiction of parliamentarism" in the puppet theater in Bordeaux and Versailles, according to a recent article Eleanor Reverzy and Nicolas Bourguinat in Cahiers columnist opposes a lyrical speech and generous" and yet how wonderful opportunity to talk with all his heart and all his intelligence! A man of superior intellect, facing this young audience, quivering with hope and life, find, it seems to me, sublime tenderness of cries; it would have the intuition of tomorrow. The speech I would dream of men. The entire audience would rise to acclaim and all over France would keep in a long emotion [...] It would be an appeal to the generation that will follow us [...] It seems the need to educate the humblest $[. .$.$] in front of these young men, he would feel$ 
a poignant emotion: he would speak to them as to the workers who will complete to establish the great society of the twentieth century. I do not know yet what he would say, but I feel it could make high eloquence work."We admire the staging of great speeches, rhetoric utopia where coincide prophetic generosity of the idea and persuasive seduction of shape heralds accents of scientific faith Zola or the great work of the Rougon-Macquart, Curious paradox of an anti-speech, a dream of speech that sounds like a manifesto zolienne thought.

Raspail and embodied in a moving chronicle of La Cloche, dated 14 June 1870" The gaiety of the House", this pure word, almost sacred, "which never intervenes in matters of humanity," face the vanity of politicians speeches, laughter fat and grinning, topos romance of the century reminded by Marie-Ange Fern in his article in Cahiers "Portrait of Zola columnist": "the other day, amidst laughter, Raspail say this sentence:" the one you laugh, gentlemen, was raised in the school of misfortune. I have seen the suffering of the prisoner locked in moisture in the dirt, without even a broom at his disposal."At this word broom, you know, the House there is more [...] you have heard: broom, he said. Broom God Raspail whether it is funny [...] He continues! His tired voice:"Never, as for me, I will not tolerate anyone; anyone suffering is a public prosecutor.' [...] Not one of these gentlemen did seem to doubt that the words that have just fallen from the platform are quite simply sublime." I refer again to a section of Papers, written by Marie-Astrid Charlier,"the broom against the probe, Zola columnist end of an Era (La Cloche, 1870)", which, between the sweepings to the remains, the letter in mind, suggests well the power of words when they return to the truth of the same things-the broom Raspail, the "village" anonymous soon made history and wiped off the map-face the metaphorical objects-the probe of the Emperor in the "Old scrap" or sophisticated doll Catherine in the eponymous chronic.

Finally, note how in this text the word zolienne opposes his speech simply dazzling and lightning, in this case the sarcarstique aphorism "It's so funny, heart, true emotion" to intertextuality in which the journalist says writer already, as if the cultural reference was paradoxically both a negative marker and the weapon of satire against the royalists puppets" Jérôme David (in) thundering Jupiter, M Duvernois (in) demigod climbing Olympus" Marie-FrançoiseMelmoux Montaubin, in his article" the Parisian Letters: news and seriality in the daily press, "sees this intertextuality" posture"already" a writer."Need we recall that many speeches peppered the RougonMacquart and that facing the utopian discourse but a little smoky Etienne in Germinal, dominate official discourse, verbose and formalists such inaugurated in Niort railway by Eugene in chapter X of His Excellency Eugène Rougon or liberal recantation of the Minister at the end of the novel? Fictional discourse and sycophants Victor Duruy and Eugène Rouher shadows of the deputies of the legislative body in a chat Tribune, August 2, 1868, seem to advance derealize by prosopopoeia parodic speech to the Imperial baptism opens the novel and taken other official word.

The dialogs offer the same ambivalence between the factual and fiction, one feeding on the other in various forms: thus, the parliamentary debate on the Ravinel proposal to install all the powers in Paris leads to an allegorical dramatization personifying Paris and the provinces in their implementation mutual accusation and a booklet moralizing peddled in Paris on girls youth education instruction for the older girls who want to marry and to which they must if they want conformer quickly find a good party seems to parody in a grotesque litany of foolish and stupid Demands Answers; conversely, the fictionalized dialogue will discuss the political and literary inclinations palinodes two representatives of the classical academy died in 1868 and Viennet Limayrac in "milky dawn" dialogue of the dead who paints a historical picture imprinted an indulgent wisdom. More ironically, a discussion with the devil enshrined in the chat Tribune of July 5, 1868"AM ${ }^{\text {gr }}$ Bishop of Aire" mocks superstition and obscurantism maintained by the Church against the progress and free thinking embodied by the devil...! Nice balance between the chestnut called the heart of the recess and the series of 14 resolutely literary texts compensating for the readers of The Bell vacuum of news, the story dialogued" Holiday Rapier" features ridicule outdated a Breton monarchist, that his wife is cheating with a Republican elected councilor cousin, who, returning from Versailles, is accused in a tasty dialog not being able to install in six months Henry V on the throne and $\mathrm{n}$ have not declared war on Italy to help the pope to take Rome.

Yet the dialogue itself in chronic occupies less space than the letter, constitutive of the Republic march since the articles themselves as Letters of Bordeaux or Versailles addressed to players or to the director of La Cloche: the author can deploy and condense all aspects of writing at once intimate and public, in a variety of registers and exceptional enunciative polyphony-be it the voice of the writer or those characters. No less than twenty letters punctuate the Chronicles and Controversies, that is the most literary part, most worked in our corpus. None of these embedded or integral epistles came out to pure autobiographical confession or, conversely, to the militant extroversion, argumentative of the open letter: Zola chose to make these letters literary texts, playful and parodic-a bit like the epistolary novel-to argue or make political and moral message, beyond the seemingly lyrical or didactic register. They occur most often as allegorical or fictitious letters open letters Zola himself or characters, familiar or exotic, the columnist. We remember the last column of Zola at the beginning of the 1870 war"Nerves of France" or the talk "France, I wish you a happy new year" based on allegory and familiarity of France, inquiries and all the terms of the exhortation and prayer. One could also mention the talk addressed to Manon, exalting an imaginary woman, archetype for Zola's simplicity and natural. This is an opportunity for praise of nature and, conversely, a critique of worldliness, of artificiality, of poissards shows or rich, corrupt women-in short, this murky world and shimmering that denounce later The Quarry or Nana. The epistolary approach here is clearly that of a moralist pamphleteer. Monologues inserted on Love Field and unlike worldly celebrations descriptions punctuate this letter succeeds in giving life to a dream: the realistic and familiar illusion of beginning -" Manon, my dear, you're right; I neglected you "opposes the surprise and final demystifying effect:" Oh! I would like you, if you exist, Manon, my dear ghost".

Another type of letters to the Chinese Ambassador to FatumaDjombé, Queen of Mohely or "At one claiming" the throne of France, King of Araucania and Patagonia, play both exotic fantasy wildest and expensive fictional scenery Montesquieu, the operetta kings sought acting Persian traveler who holds up a mirror of France's second Empire and the public mind deliquescent. More personalized, "The humble supplication" Zola monarchist deputies prefer a change of scenery the game on the records: it affects the supplication and confidence to mask the vehemence of the anti-monarchical indictment. 
The irony takes the mask of pathos, like Montesquieu in his famous "Very humble Remonstrance to the Inquisitors of Spain and Portugal" in The Spirit of Laws: Zola plays humility and respect for the simple parliamentary columnist praying these royalists so gloomy, described elsewhere as "ghosts" to return to Paris. It then advances to better reject the excuses he could invoke to achieve its goals: anaphora decline in this unreal form that could take this plea: "I can certainly tell you that Paris is peaceful"; "I could still tell you about the festivals of the Elysee. The feigned seriousness and irony finally gave way to anger forcefully prétéritions-so the letter appears as the melting pot of all registers and feelings:" No. I will not give you any of these wrong reasons, I will not put forward or the peace of the country or the country suffers, nor common sense who is angry or Paris who makes fun of you or who M. Thiers done as much [...] no, I will not do any of those things, I just bow to you and I will tell you:"' I've had enough, we all have enough. Return to Paris, do not lock them further with you in Versailles [...]" This, gentlemen, the humble supplication dares you send a press worm."

A final set of letters was supposedly written by fictional characters but mostly familiar, modest political or simple anonymous men: a rifleman, a hatter, a deputy on tour, Mayor Fouilly-the-Geese offering hospitality "his Majesty country" Napoléon III if the Emperor were to lose power, or a politically cautious and conservative uncle rabrouant its subversive nephew. Paradoxically, these letters lent to popular letter writers, where could recognize any French player at the end of the second Empire, seem both more factual-as rooted in the political reality of an end system-also because more fictional literarily more elaborate than the allegorical or exotic letters, where the scenery sometimes reported to a intertextual game and established a distance mitigating the controversy. Satire wins here in simplicity and the local look, tied to an internal point of view, seems more instructive than the exotic look: the character tells his daily experience of politics, doubts or misunderstandings, reveals his servility or his growing revolt. The zoliennes chronic and seem in many ways to slip into the matrix of the intimate writing: they take an epistolary form in many articles or diarist as the minutes of the draft treaty to the Assembly in the form of diary; they meet a waiting readership that wants to see the journalist to stage, take as Bordeaux February 28, 1870 "mourning clothes"; they finally fall which is Marie-Eve Therenty in Literature every day a compromise between the new regime of information based on the primacy of fact and tradition of literary journalism, "the thing seen." The most personal lyrics Zola seem indeed raise an artist writing and take the form of strolls or meditations in the articles of 1868-1870.

The writer-journalist and proposes three important articles: chronic-walk Gloton, hymn to nature unfolding in praise of science, "epic" (naturalist)"tomorrow" and tribute poems Michelet; autumnal talk on the fairgrounds of Saint-Ouen, allowing Zola exalt the people, it's simple pleasures face the squares and Mr. Haussman cabins and to call for a "Plain of workers and workers"; a dream finally cemeteries, meditation on death and distant battlefields. The same lyrical movement anime, one passing anecdote or the mention of a moral, symbolic referred halfway, at least in the apparent form of informative and polemical: it is as if Zola tried here, with chat, an original form of critical lyricism or poetic argument. This text demonstrates a great work style and a marked about the dramatization. Zola offers us a great talk on the cemeteries, memorial and romantic place par excellence since he likes devotes other chronic, including a half- disgusted meditation, half nostalgic of Montmartre and Pere Lachaise. Chronic from a "walker solitary reverie"; daydreaming, in turn, will try and unfolds in meditation, over the thoughts, by association of ideas-or reconciliations antitheses." The day of the Feast of the Dead, I followed the crowd, I went under the pale November sun, see flowers on the graves" -wrote the walker, generalizing soon experience a plural space and abstraction lyrical:"Cemeteries of Paris awaken me great sadness. The feeling is then thought to oppose the consistency and the brotherhood of peaceful village cemeteries anonymity and social inequality "rest areas" Parisians.

The reflection is then returned to the experience: "I went last Monday at the edge of the grave." Zola overall plan then focuses on the underprivileged of our cemeteries, the "mass grave." For further enlargement opens a meditation with the words" miserable little black cross" and "field misery" give the melancholy tone: literary mediation intervenes here with" a wonderful page" of Germinie Lacerteux the Goncourt brothers. Therefore, the talk of Zola becomes a magnificent funeral lament, as if she was only here his real start. Zola first calls for compassion for the people to a dignified burial: "Certainly, the people do not need marble tombs to rest of his long life of misery and labor. But why not let a little earth after death to those who have nothing possessed in their lifetime?" The general view is reflected in a living picture, making return to the initial loitering" on Monday, I saw men in blouses, poor women shivering in their thin dark dress." The table finally s' individualizes in a moving scene, with dialogue and narrative, between the columnist and a little old "as I walked, I saw an old woman who wandered sadly from the cross. She did not seek person walking in front of her, watching the desperation of others with poignant desires."The old woman offers the pathetic vision of a woman crying her three son," one death in the Crimea, the other in Italy, the third in Mexico"," (that) sleeping in some corner lost" She asks columnist and custodian of his suffering, the direction of Sevastopol, as it does not even know where to turn to pray for his older! Lyricism culminates in a general lamentation of war in a last vision, lyrical and striking: "I wish that everyone might see me as the little old lady asked which side was poor and Sevastopol, praying hands clasped, staring on the distant horizon."And that vision is the second indictment against Empire and its distant battlefields to the dead unburied.

I will end my presentation by mentioning the pamphétaire dimension that drives many chronic, particularly those from the late Second Empire, such as chat Tribune, August 29, 1869, celebrating the memory of having to face the coup regime founder on the occasion of the publication of the book Christmas Blache History of the insurrection of the Var in December 1851 matrix the Fortune of Rougon. Here is the opening lecture of the text:"stubbornness has been criticized for democracy in hatred some people, accomplished facts must be forgiven and after a more or less long I wonder on what calculation. These people rely forgotten crises. Should decade, it must be twenty years for a bad action becomes good? [...] the human conscience cannot have these compromises and still a generation would be cowardly enough to forget a cursed date, impartial history would be there, that cry to posterity: "that day, at such time, the right has been violated and France bruised." This preamble rich anaphora, antithesis and rhetorical questions, anchor the entire column in the register of the indictment, although the result will reflect an apparent calming of words and some textual variety: Christmas presentation 
Blache-the child asking his grandfather before the arrest of Republicans in the aftermath of the coup then became a lawyer adult, author of a history of insurgency Var in December 1851); back to thinking about the authenticity of this testimony and, conversely, the imperial disinformation that has Republicans as murderers, framing a reminder of the facts, the great democratic emergence (peaceful) department; Finally, large quotes from the book of M. Blache, reporting the murder of Besson, quotes themselves interrupted near the end by seemingly informative remarks on the release of another witness, Memoirs of a shot, Giraud, weaver Luc, who received a pistol in the ear of Mayère policeman. We know how this drama will be recycled at the end of The Fortune of Rougon with the murder of Silvère by Rengade policeman.

For historical prolepsis by calling the judgment of posterity, the stigma of a manipulator and impregnable opponent-the regime and its supporters,"some people","these people"-its moral intransigence in the name of"right" and the"human conscience", this superb text reports to the pamphlet which he would illustrate the three main characters of Marc Angenot in the pamphleteer Word: a solitary and vehement truth, the author feels depositary and explains his indignation ; sentiment also irresistibly deception against which appeal to a universal audience-readers? Posterity-to fight the invisible enemy ; Finally, to a lesser extent as Zola believes in human progress and the march of history, a twilight world view, at least in the tone of the text. The same virulence holy prophet seems to animate two texts directed one against the decay of morals under the Second Empire, the other against the moral order which excludes illegitimate children of exemption from military service-the blind moralism "clerical whip."Sensitive in the formula in free indirect style" Down with the illegitimate children these are the damned"- monologue Baron? Sarcasm columnist: joining the unbridled immorality in the same opprobrium.'Listen, here's where the Empire has come, this is the generation that was brought into the world [...] It's clean and the feast is complete. Really the Empire has made us a great nation. These our men become women. When Rome was rotting in his greatness, it has not done other miracles. The beautiful nights of ancient orgy returned, the burning nights where the creatures had more sex [...] they were bound to happen. "This text, known for heralding the founder and motive the Quarry, thus punctuated by vigorous formulas or arrests celebrating the performative virtue of the word pamphleteer, only action against the scandal and the triumphant perversion of the truth:" Look, here's where the Empire has come, this is the generation that was brought into the world." Earlier, columnist exclaimed:"Ah, what spoils the Second Empire the day after the coup, the orchestra beat the first steps of the waltz and the languorous theme quickly became a gallop diabolical. They put their hands on the flat, right in the sauce, eating greedily, tearing pieces of the mouth. They rushed to the satisfaction of their appetites with a beast of passion [...] $\mathrm{N}$ 'is not that the hard scramble for quite long years and it's time to end it?"

The theme of the quarry is linked here to the grounds of the banquet and ball, which as part of a satirical book, that of a corrosive irony, jubilant and an inverted world and carnival, against which Zola seems to hesitate between a aesthetic vision and ethics referred as Gilquin the character of His Excellency Eugène Rougon between buffoonery and dirty work. Thus, articulation and chronic cycle of Rougon-Macquart she Zola is an epistemological break akin journalistic approach to novel writing: after personal novels, from his pure imagination as Thérèse Raquin or Madeleine Férat, Zola combine fictional invention and moral and political satire (from the documentary tank chronic), thus founding fiction of moral analysis of a company.

\section{Acknowledgements}

None.

\section{Conflict of interest}

Author declares that there is no conflict of interest. 